\title{
QUANTIFICATION OF STREPTOCOCCUS SANGUINIS ISOLATED FROM DENTAL PLAQUE AND SALIVA OF SUBJECTS WITH AND WITHOUT CORONARY HEART DISEASE - ANALYSIS USING REAL-TIME PCR
}

\section{(KUANTIFIKASI STREPTOCOCCUS SANGUINIS YANG DIISOLASI DARI PLAK DAN SALIVA GIGI SUBYEK DENGAN DAN TANPA PENYAKIT JANTUNG KORONER DENGAN MENGGUNAKAN PCR REAL-TIME)}

\author{
Aini Hariyani Nasution*, Yulianti Kemal**, Robert Lessang**, Boy Bachtiar*** \\ *Department Periodontology, Faculty of Dentistry University of Indonesia \\ **Department of Periodontology, Faculty of Dentistry University of Indonesia \\ ***Department of Oral Biology, Faculty of Dentistry University of Indonesia
}

\begin{abstract}
Coronary Heart Disease (CHD) is the major cause of death in most countries in the world. Gram-positive and Gramnegative bacteria have been identified in bacteremia cases and known to have a role in various vascular diseases, including Streptococcus sanguinis which is most frequently isolated from endocarditis patients and often associated with CHD. The purpose of this study was to analyze the number of Streptococcus sanguinis isolated from dental plaque and saliva of subjects with and without CHD. Bacterial colonies isolated from the dental plaque and saliva of 16 subjects without CHD and 8 subjects with CHD were planted in Mitis salivarius agar, and then the DNA was extracted and quantified with a Real-Time PCR technique using 16S rRNA specific primers. The quantification of Real-Time PCR showed that there was a difference in the number of $S$. sanguinis between the two groups of subjects, but an unpaired Ttest showed that the difference was not statistically significant. Furthermore, the number of S. sanguinis from dental plaque in CHD subjects tends to be higher than that of non-CHD subjects whereas the number of $S$. sanguinis from saliva in non-CHD subjects tends to be higher than that of CHD subjects.
\end{abstract}

Key words: coronary heart disease, real-time PCR, Streptococcus sanguinis

\begin{abstract}
Abstrak
Penyakit Jantung Koroner merupakan penyebab utama kematian di dunia. Bakteri positif Gram dan negatif Gram telah sering diidentifikasi pada bakteremia dan disebut memiliki peran dalam penyakit vascular, termasuk Streptococcus sanguinis yang paling sering diisolasi dari pasien endokarditis dan sering dikaitkan dengan PJK. Tujuan penelitian ini adalah untuk menganalisis jumlah Streptococcus sanguinis yang diisolasi dari plak gigi dan saliva subjek non-PJK dan PJK. Koloni bakteri dari plak gigi dan saliva 16 subjek non-PJK dan 8 subjek PJK ditanam pada agar Mitis salivarius, diekstraksi DNA kemudian dikuantifikasi dengan teknik Real-Time PCR menggunakan primers spesifik 16S rRNA. Kuantifikasi Real-Time PCR menunjukkan perbedaan jumlah $S$. sanguinis antara subjek kelompok non-PJK dan PJK namun uji t tidak berpasangan menunjukkan perbedaannya tidak signifikan. Pada subjek yang menjadi sampel penelitian ditemukan kecenderungan jumlah $S$. sanguinis asal plak gigi subjek PJK lebih tinggi dibandingkan subjek non-PJK dan jumlah $S$. sanguinis asal saliva subjek non-PJK cenderung lebih tinggi dibanding subjek PJK.
\end{abstract}

Kata kunci: penyakit jantung koroner, real-time PCR, Streptococcus sanguinis

\section{INTRODUCTION}

Coronary Heart Disease (CHD) is still the leading cause of death in the world. ${ }^{1-5}$ Myocardial infarction, the first sequence of death causes, is commonly caused by $\mathrm{CHD}{ }^{6}$ Gram-positive and Gram-negative bacteria have been frequently identified in bacteriaemia and are said to have a role in vascular diseases. ${ }^{7}$

Streptococcus sanguinis is a Gram-positive bacteria which is a major component in the normal flora 
of the mouth. ${ }^{8,9}$ Streptococcus sanguinis has been reported to be closely related to the occurrence of infective endocarditis which is often caused by the entry of bacteria into the bloodstream due to trauma. ${ }^{10}$ Moreover, Streptococcus sanguinis is one of the most isolated organisms from dental plaque, one of the most frequently isolated organisms from patients with sub-acute bacterial endocarditis ${ }^{11}$, and often associated with coronary heart disease. ${ }^{10,11,12}$

A study by Johansson et al. found that periodontal diseases were higher in prevalence in CHD patients than in healthy subjects. ${ }^{1}$ Another study conducted by Nakajima et al. showed that periodontitis was a risk factor for the occurrence of Coronary Heart Disease. ${ }^{2}$ Moreover, Hujoel et al. also conducted a study to evaluate the risk of CHD in subjects with periodontitis, gingivitis, and healthy periodontium. The result of this study did not show a causal relationship between periodontal diseases and the risk of CHD. ${ }^{13}$

Spahr et al. investigated the relationship between periodontitis and CHD which was seen from microbiological characteristics of periodontitis. This study found a strong and significant relationship between the number of periodontal bacteria and CHD. ${ }^{4}$ Another study by Nakano et al. found $S$. sanguinis on a tissue taken from the heart valve and atheromatous plaque specimens taken from patients undergoing cardiac surgery. ${ }^{14}$ In addition, Deng et al. and Chen et al. proved an increase in the number of S. sanguinis in saliva and dental plaque of CHD patients. ${ }^{15,16}$

The present study was conducted to determine the number of Streptococcus sanguinis isolated from dental plaque and saliva of non-CHD subjects compared with CHD subjects using a Real-Time PCR method. This was a preliminary study for a study by Kemal et al. about $S$. sanguinis in CHD patients up to the number of genotypes.

\section{MATERIALS AND METHODS}

The subjects of this research were patients with and without $\mathrm{CHD}$, and the materials used were dental plaque and saliva collected from the research subjects. Ethical approval was obtained from the Research Ethics Committee of Dentistry, University of Indonesia. The type of research was laboratory observation.

The location of the research sampling was at Cipto Mangunkusumo Hospital and Periodontics Specialist Clinic at the Faculty of Dentistry, University of Indonesia. The measurement of the number of $S$. sanguinis was conducted at the Oral Biology Laboratory in the Faculty of Dentistry, University of Indonesia. This study was conducted from April to
June 2012. The determination of subjects whether they suffered from CHD or not was done with an ECG examination performed at Cipto Mangunkusumo Hospital, Jakarta.

Subjects examined in the present study were 24 subjects consisting of men and women with an age range of 50-60 years. Based on their smoking status, there were former smokers, smokers, and non-smokers.

The research used a consecutive sampling to determine the research subjects in which a minimum number of samples were 16 samples. The sample criteria were as follows: (1) CHD or non-CHD subjects determined by an ECG examination; (2) an accumulation of plaque on the teeth and production of saliva; (3) aged of 50-60 years; and (4) willing to participate in the research and signed informed consent. The exclusion criteria were pregnant women and uncommunicative patients.

The work procedure started by making mitis Salivarius agar. The measurement of the plaque score, calculus, periodontal index, and OHIS score was done according to their respective measurement criteria. Afterward, the dental plaque of the subjects was collected on the lingual side of the lower anterior teeth by swabbing. Then, the samples were inserted into a $1.5 \mathrm{ml}$ Eppendorf tube filled with sterile PBS fluid, sealed, and labelled with a name and code. Saliva samples were obtainnned after holding it for 5 minutes in the mouth without stimulation.

The bacteria were bred on a selective medium of mitis salivarius using a glass inoculating loop and were inserted into an anaerobic tube for incubation at the temperature of $37^{\circ} \mathrm{C}$ for 3 days. Then a dilution series and calculation of $S$. sanguinis control bacteria was done to determine the $\mathrm{CFU} / \mathrm{ml}$ value used as the standard value in the PCR Real-Time amplification process.

The DNA extraction of the bacteria used GeneJETTM genomic DNA Purification Kit (Fermen$\operatorname{tas}()$ ). A $5 \mu$ of the extracted DNA was collected and inserted in a cuvette for spectrophotometry. After that, DNA amplification was conducted by using Real-Time PCR. The calculation of the number of bacteria was obtained from the dilution of $S$. sanguinis culture planted on mitis salivarius agar base.

\section{RESULTS}

Primary data was collected through clinical examination in the form of plaque accumulation, calculus accumulation, electrocardiogram examination, and laboratory work to determine the number of $S$. sanguinis isolated from dental plaque and saliva. 
The number of subjects examined was 25 subjects. Based on an ECG examination, 16 subjects were healthy (non-CHD), 8 subjects suffered CHD, and 1

Table 1. Distribution of Demographic Data for Gender and Smoking Status subject was eliminated for not having an ECG examination.

\begin{tabular}{|c|c|c|c|c|c|c|c|}
\hline \multicolumn{8}{|c|}{ Group } \\
\hline \multirow[t]{2}{*}{ Variable } & & \multicolumn{2}{|c|}{ Non-CHD } & \multicolumn{2}{|c|}{ CHD } & \multicolumn{2}{|c|}{ Total } \\
\hline & & $\mathrm{n}$ & $\%$ & & $\%$ & $\mathrm{~N}$ & $\%$ \\
\hline \multirow{2}{*}{ Gender } & Male & 12 & $75.0 \%$ & 6 & $75.0 \%$ & 18 & $75.0 \%$ \\
\hline & Female & 4 & $25.0 \%$ & 2 & $25.0 \%$ & 6 & $25.0 \%$ \\
\hline \multirow{3}{*}{$\begin{array}{l}\text { Smoking } \\
\text { Status }\end{array}$} & Former smoker & 3 & $18.8 \%$ & 4 & $50.0 \%$ & 7 & $29.2 \%$ \\
\hline & Smoker & 7 & $43.8 \%$ & 3 & $37.5 \%$ & 10 & $41.7 \%$ \\
\hline & Non-smoker & 6 & $37.5 \%$ & 1 & $12.5 \%$ & 7 & $29.2 \%$ \\
\hline
\end{tabular}

The results of a univariate analysis in Table 1 showed that most of the subjects were male $(75 \%)$ with the number of smokers reached $42 \%$.

In the non-CHD group, the number of subjects where the quantification of $S$. sanguinis from dental plaque samples were successful with the Real-Time PCR technique was 15 , whereas in the CHD group there was only 7 subjects that were successfully quantified. Quantification of $S$. sanguinis from saliva samples were all successful in 24 subjects.

Table 2. The Number of Streptococcus sanguinis from Samples of Dental Plaque and Saliva

\begin{tabular}{lcccccc}
\hline & Mean & $\begin{array}{c}\text { Standard } \\
\text { Deviation }\end{array}$ & Median & Minimum & Maximum & Distribution \\
\hline $\begin{array}{l}\text { The number of S.s from plaque* } \\
\text { (CFU/ml) }\end{array}$ & 50.32 & 167.37 & 0.01 & - & 806.50 & Non-normal \\
$\begin{array}{l}\text { The number of S.s from saliva* } \\
(\mathrm{CFU} / \mathrm{ml})\end{array}$ & 501.63 & 2.323 .89 & 0.02 & 0.00 & $11,407.50$ & Non-normal \\
& 11.36 & 1.86 & 10.45 & 9.28 & 14.91 & Normal \\
$\begin{array}{l}\log \text { CFUplaque } \\
\log \text { CFUsaliva }\end{array}$ & 11.39 & 2.03 & 10.23 & 9.10 & 16.06 & Normal \\
\hline$*$ in trillion units $\left(10^{12}\right)$ & & & & & &
\end{tabular}

*) in trillion units $\left(10^{12}\right)$

Note: For the normal distribution, valid parameters were mean and standard deviation whereas for non-normal distribution data, valid parameters were median, minimum values, and maximum values. 
Table 2 shows the total number of Streptococcus sanguinis bacteria from dental plaque and saliva samples of the non-CHD and CHD groups based on calculations using the Real-Time PCR method. In the case of normal distribution, the data were transformed by Kolmogorov-Smirnov test in the form of $\log$ values of the total number of $S$. sanguinis from dental plaque and saliva samples.

Table 3. Transformation values comparison in the number of $S$. sanguinis from samples of dental plaque and Saliva between non-CHD and CHD subjects.

\begin{tabular}{llcc}
\hline Group & $\begin{array}{l}\log \mathrm{CFU} \\
\text { Plaque }\end{array}$ & $\begin{array}{c}\log \mathrm{CFU} \\
\text { Saliva }\end{array}$ & p-value \\
&
\end{tabular}

Average SD Average SD

\begin{tabular}{llllll}
\hline $\begin{array}{l}\text { Non- } \\
\text { CHD }\end{array}$ & 11.13 & 1.62 & 11.60 & 2.01 & 0.413 \\
CHD & 11.84 & 2.35 & 10.98 & 2.13 & 0.493 \\
\hline
\end{tabular}

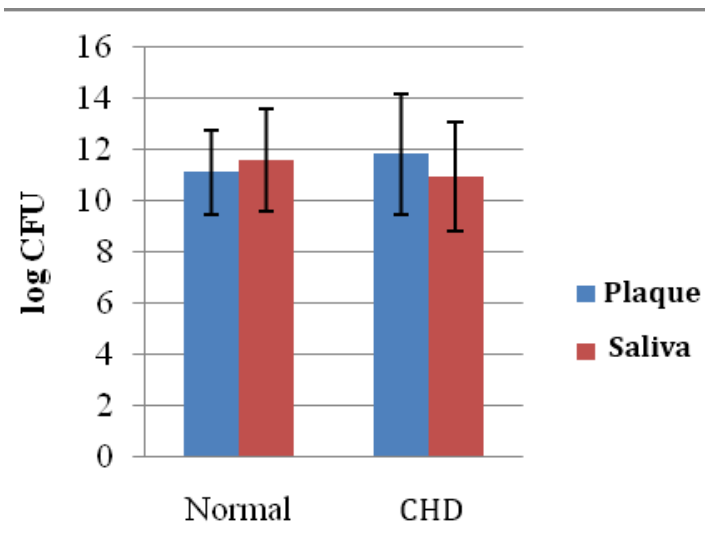

Group

Figure 1. Comparison of S. sanguinis bacterial counts from dental plaque and saliva samples in the non-CHD and CHD groups

Table 3 and Figure 1 show a difference in the log$\mathrm{CFU} / \mathrm{ml}$ value of $S$. sanguinis from dental plaque and the $\log \mathrm{CFU} / \mathrm{ml}$ of $S$. sanguinis from Saliva between subjects in the non-CHD and CHD groups. As shown, the $\log \mathrm{CFU} / \mathrm{ml}$ value of $S$. sanguinis from dental plaque of the CHD subjects was higher than the non-CHD subjects.

However, an unpaired T-test result found no significant difference between $\log \mathrm{CFU} / \mathrm{ml}$ value of $S$. $s a$ nguinis from plaque in both groups $(p=0.413)$.

Furthermore, Table 3 and Figure 1 show that log $\mathrm{CFU} / \mathrm{ml}$ value of $S$. sanguinis from saliva for nonCHD subjects was slightly higher than that of the CHD subjects although the unpaired T-test result found no significant difference between $\log \mathrm{CFU} / \mathrm{ml}$ of $S$. sanguinis values from saliva in both groups $(p=0.493)$.

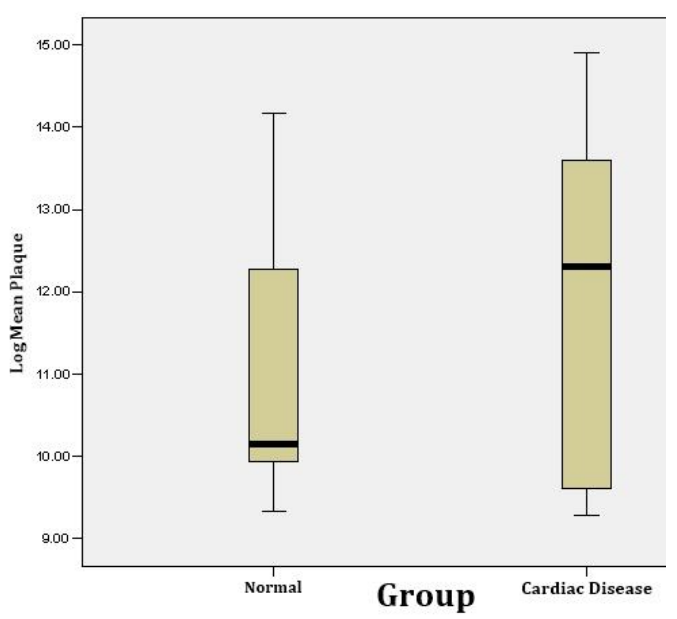

Figure 2. The number of $S$. sanguinis bacteria from plaque samples in the non-CHD and CHD groups

Figure 2 shows a boxplot diagram depicting the $\log \mathrm{CFU} / \mathrm{ml}$ value of $S$. sanguinis from dental plaque between the non-CHD and CHD subjects. As shown, the $\log \mathrm{CFU} / \mathrm{ml}$ value of $S$. sanguinis from dental plaque of the CHD subjects was higher than that of the non-CHD subjects although the differrence was not statistically significant.

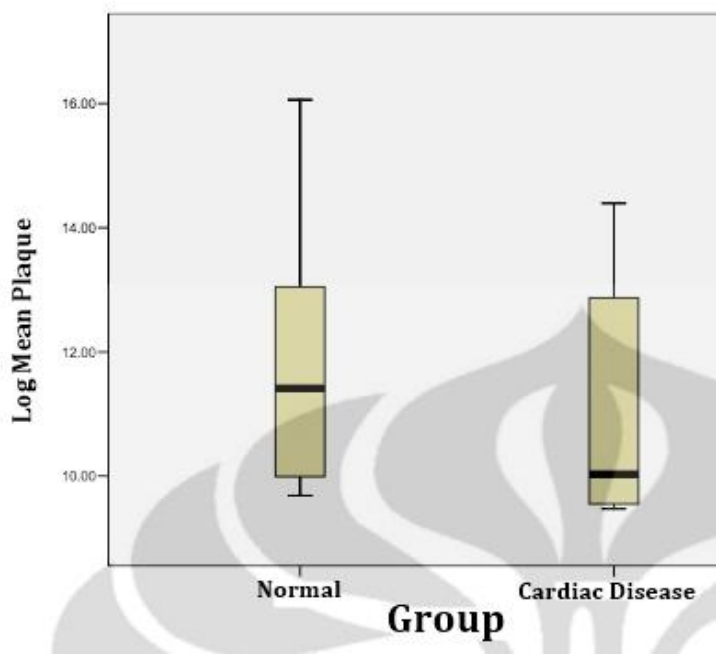

Figure 3. The number of $S$. sanguinis bacteria from saliva samples of the non-CHD and CHD groups

Figure 3 shows a boxplot diagram depicting the comparison of $\log \mathrm{CFU} / \mathrm{ml}$ of $S$. sanguinis from saliva between subjects in the non-CHD and $\mathrm{CHD}$ 
groups. It is seen that the $\log \mathrm{CFU} / \mathrm{ml}$ value of $S$. $s a$ nguinis from the saliva of the non-CHD subjects was higher than that of the CHD subjects, but the difference was not significant statistically.

The data obtained were then analyzed by ROC to see if the number of $S$. sanguinis bacteria in the dental plaque and saliva samples could be used to distinguish non-CHD and CHD subjects.

Table 4. ROC analysis to see the number of Streptococcus sanguinis from the samples of dental plaque and saliva in distinguishing non-CHD and CHD subjects

\begin{tabular}{|c|c|c|c|c|c|}
\hline $\begin{array}{l}\text { Test } \\
\text { variable }\end{array}$ & Area & $\begin{array}{l}\text { Std. } \\
\text { Error } \\
\text { (a) }\end{array}$ & $\begin{array}{l}\text { Asympto } \\
\text { tic } \\
\text { Sig.(b) }\end{array}$ & $\begin{array}{r}\text { Asymp } \\
\text { Confider } \\
\text { Lower } \\
\text { Bound }\end{array}$ & $\begin{array}{l}\text { tic } 95 \\
\text { e Inte } \\
\text { Upp } \\
\text { Bou }\end{array}$ \\
\hline & & .1 & & .1 & .809 \\
\hline $\mathrm{CFU}$ & 62 & 152 & .341 & .3 & .926 \\
\hline
\end{tabular}

a Under the nonparametric assumption

b Null hypothesis: true area $=0.5$

Table 4 shows the analysis results of ROC showing that the number of $S$. sanguinis from dental plaque and saliva samples was not sensitive to distinguish non-CHD and CHD subjects. This result was obtained from an insignificant p-value in $\log$ $\mathrm{CFU} / \mathrm{ml}$ of $S$. sanguinis from dental plaque ( $p=$ $0.916)$ and $\log \mathrm{CFU} / \mathrm{ml}$ of $S$. sanguinis from saliva $(p=0.341)$.

\section{DISCUSSION}

The purpose of this study was to analyze the number of $S$. sanguinis isolated from dental plaque and saliva samples of the non-CHD and CHD subjects. The sample collection from the research subjects was conducted at the Periodontics Clinic of Dental and Mouth Hospital, Faculty of Dentistry, University of Indonesia.

The number of subjects recruited was 24 subjects in whom most of the subjects were male $(75 \%)$ and the number of smokers reached $42 \%$. Moreover, the age range of the subjects was a minimum 50 to a maximum 60 years old. This age range was selected because cholesterol level during this age range is the highest, so it also has a high risk of $\mathrm{CHD} .^{21}$

Primary data was collected through a clinical examination of Plaque Index, Calculus Index, Periodontal Index, OHIS, and laboratory examination in the form of $S$. sanguinis quantification examined from dental plaque and saliva. The laboratory examination was conducted at the Oral Biology Laboratory, Faculty of Dentistry, University of Indonesia.
The examination of dental plaque and saliva samples collected from the subjects was performed with Real-Time PCR using universal primers. The advantages of using the Real-Time PCR technique are including high sensitivity and specificity, also quick and effective calculations. ${ }^{17}$ In addition, the bacterial samples which will be counted with the Real-Time PCR should not necessarily be alive, and the samples remain stable for long-term storage if frozen.

Real-Time PCR with specific primers will generate accurate and sensitive methods for the identification and quantification of species and bacterial populations (i.e. total bacteria) obtained from the study samples. Primers used in this study were $16 \mathrm{~S}$ rRNAs because these primers were particularly useful for the detection and quantification of bacteria in various environments and health-related situations in which the sample was a multi-species and impure population. ${ }^{19}$

The quantification method used to calculate the number of bacteria in this study was the absolute quantification which was a quantification of bacteria in a sample based on the relative comparison to the 16S rRNA amplification results of the standard bacteria and by using the pure strain bacterial standard of the American Type Culture Collection. The absolute quantification produces the exact number of targeted DNA molecules by comparison with standard bacterial DNA. The total number of $S$. sanguinis bacteria was obtained from the calculation based on the conversion value of the $\mathrm{C}_{\mathrm{T}}$ value. ${ }^{20}$

Spahr et al. measured directly the number of periodontal pathogens and found that an increase in the number of periodontal pathogens was associated with an increase in the incidence of CHD. ${ }^{4}$ A study by Chen et al. who took plaque samples from subgingival plaques showed that $89 \mathrm{he}$ number of $\mathrm{S}$. $\mathrm{sa}$ nguinis in plaque and saliva of CHD patients was significantly higher than that of healthy patients. ${ }^{15} \mathrm{In}$ the present study, the number of $S$. sanguinis from dental plaque samples of CHD subjects was higher than that of the non-CHD subjects. However, the difference was not statistically significant due to the small number of samples. This is in accordance with the results obtained by Chen and colleagues. This result also corresponds to an increase in the number of periodontal pathogens in CHD subjects found by Spahr and colleagues.

In this study, S. sanguinis from the saliva samples of the non-CHD subjects was slightly higher than that of the CHD subjects, but the difference was not statistically significant. This raises the assumption that the difference occurs because of the different strains of $S$. sanguinis in plaque and saliva. It is possible that the strains of $S$. sanguinis which have a ro- 
le in forming biofilms in adhesions on the teeth surfaces are more prevalent in CHD subjects. To prove this assumption, further research is needed.

McNicol et al. conducted a study to determine the role of immunoglobulin $\mathrm{G}$ in relation to cardiovascular diseases caused by bacteria, especially $S$. sanguinis. This study concluded that platelet activation depended on IgG and its bonding with the strains of S. sanguinis. Among four strains studied, three strains showed a significant number of $\operatorname{IgG}$ while the other strain had a low bond, so platelet aggregation was regulated by the extent to which the IgG bond responded to the presence of $S$. sanguinis. ${ }^{22}$ The results of this study showed that strains present in nonCHD and CHD might differ.

According to the literature, there is a similarity in the composition of bacteria in saliva and the tongue. The tongue is a considerable reservoir of $S$. sanguinis, and this explains the high number of $S$. sanguinis in saliva. ${ }^{23}$ Therefore, an increase in the number of $S$. sanguinis in dental plaque does not reflect the number of $S$. sanguinis in saliva. Oral streptococcal colonization on the teeth surfaces depends on the adhesion of bacteria to the components of saliva adsorbed onto the teeth surfaces. ${ }^{8}$ Studies showed that some of the saliva components namely proline-rich protein, agglutinin, and $\alpha$-amylase were proven to

\section{REFERENCES}

1. Starkhammar Johansson C. Richter A, Lundström A, Thorstensson H, Ravald N et al. Periodontal conditions in patients with coronary heart disease: a case-control study. J Clin Periodontol 2008; 35(3): 199-205.

2. Nakajima T and Yamazaki K. Periodontal disease and risk of atherosclerotic coronary heart disease. Odontology 2009; 97(2): 84-91.

3. Navkiran, Kaur S, Vandana, Ashish. A study on the evaluation of periodontal status in patients with hyperlipidemia. IJCDC 2011; 1(1): 47-52.

4. Spahr A, Klein E, Khuseyinova N, Boech C, Muche $\mathrm{R}$, Kunze $\mathrm{M}$ et al. Periodontal infections and coronary heart disease: a role of periodontal and importance of total pathogen burden in the coronary event and periodontal disease (CORODONT) study. Arch Intern Med 2006; 166(5): 554-559.

5. Fong IW. Emerging relations between infectious diseases and coronary artery disease and atherosclerosis. CMAJ 2000; 163(1): 49-56.

6. Fallon JT. Pathology of myocardial infarction and reperfusion.In: Fuster V, Ross R and Topol EJ. eds. Atherosclerosis and cronary artery disease. 5th ed. Philadelphia: Lippincou Raven, 1997: 791-96.

7. Mahendra J, Mahendra L, Kurian VM, Jaishankar $\mathrm{K}$, Mythilli R et al. 16S rRNA-based detection of bind to oral streptococci. Okahashi et al. found that the structure of $S$. sanguinis named pili binds to salivary $\alpha$-amylase and plays a role in biofilm formation on saliva-coated surfaces. It is also argued that $S$. sanguinis strains without pili are unable to form biofilms. ${ }^{8}$ This supports the assumption that $S$. sanguinis strains in plaque and saliva may be different because the structure is different between $S$. sanguinis which can and cannot form biofilms.

The ROC analysis showed that the number of $S$. sanguinis from dental plaque and saliva samples found in the subjects was not sufficiently sensitive to distinguish between CHD and non-CHD subjects because the number of samples in this study was relatively small. Therefore, this requires further research with larger samples. In conclusion, there was a difference in the number of $S$. sanguinis isolated from dental plaque and saliva of the non-CHD and CHD subjects in which the number of $S$. sanguinis from the dental plaque samples of the CHD subjects tends to be higher than that of the non-CHD subjects. In addition, the number of $S$. sanguinis from saliva samples of the non-CHD subjects tends to be higher than that of the CHD subject.

oral pathogens in coronary atherosclerosis plaque. Indian J Dent Res 2010; 21(2): 248-252.

8. Okahashi N, Nakata M, Terao Y, Isoda R, Sakurai A, Sumitomo T et al. Pili of oral Streptococcus sanguinis bind to salivary amylase and promote the biofilm formation. Microb Pathog 2011; 50(3-4): 148-154.

9. Rodriguez AM., Callahan JE, Fawcett P, Ge X, Xu $\mathrm{P}$, Kitten T. Physiological and molecular characterization of genetic competence in Streptococcus sanguinis. Mo Oral Microbiol 2010; 26(2): 99-116.

10. Yamaguchi M, Terao Y, Ogawa T, Takahashi T, Hamada S, Kawabata S. Role of Streptococcus sanguinis sortase A in bacterial colonization. Microbes and Infec 2006; 8(12-13): 2791-6.

11. Kemal Y, Oemardi M, Prasetyo S. Akumulasi Kalkulus Gigi yang Berlebihan pada Penderita Diabetes Tipe 2: Gejala Klinis Kemungkinan Menderita Penyakit Jantung Koroner. JDentistry 2000; 7(3): 549-56.

12. Cohen DJ, Malave D, Ghidoni JJ, Iakodivis P, Everett MM, You S, et al. Role of Oral Bacterial Flora in Calcific Aortic Stenosis: an animal model. Ann Thorag Surg 2004; 77 (2): 537-43.

13. Hujoel PP DM, Spiekerman C, DeRouen TA. Periodontal Disease and Coronary Heart Disease Risk. JAMA 2000; 284(11): 1406-10. 
14. Nakano K, Inaba H, Nomura R, Nemoto H, Takeda $\mathrm{M}$, Yoshioka $\mathrm{H}$ et al. Detection of Cariogenic Streptococcus mutans in Extirpated Heart Valve and Atheromatous Plaque Specimens. J Clin Microbiol 2006; 44(9): 3313-7.

15. Proceedings. Change the format to: Chen H, Zhang WD. Streptococcus sanguis group in oral cavities of coronary heart disease patients. In: International Association of Dental Research (IADR/AADR/ CADR). Proceedings of 80th General Session and Exhibition. San Diego, 2002.

16. Deng S, Chen H, Zhang W. The relativity between Streptococcus sanguis group and coronary heart disease. Zhounghua Kou Qiang Yi Xue Za Zhi 2002; 37(3): 222-4.

17. Boutaga K, van Winkelhoff AJ, VandenbrouckeGrauls CM, Savelkoul PH. The additional value of real-time PCR in the quantitative detection of periodontal pathogens. J Clin Periodontol 2006; 33 (6):427-433.

18. Yano A, Kaneko N, Ida H, Yamaguchi T, Hanada. Real-Time PCR for Quantification of Streptococcus mutans. FEMS Microbial Lett 2002; 217(1): 23-30.
19. Kuboniwa M, Amano A, Kimura KR, Sekine S, Kato $\mathrm{S}$, Yamamoto $\mathrm{Y}$ et al. Quantitative detection of periodontal pathogens using real-time polymerase chain reaction with TaqMan probes. Oral Microbiol Immunol 2004; 19(3): 168-176.

20. Pfaffl MW. Quantification strategies in real-time PCR. In: Bustin SA. ed. A-Z of quantitative PCR. La Jolla, CA: International University Line, 2004: 87-112.

21. Djohan TBA, Kasiman S. Patofisiologi dan Penatalaksanaan Penyakit Jantung Koroner. Cermin Dunia Kedokteran 1992;8:152-6.

22. McNicol A, Zhu R, Pesun R, Pampolina C, Jackson $\mathrm{EC}$, Bowden $\mathrm{GH}$ et al. A role for immunoglobulin $\mathrm{G}$ in donor-specific Streptococcus sanguis-induced platelet aggregation. Thromb Haemost 2006; 95(2): 288-93.

23. Schaeken MJ, Creugers TJ, Van der Hoeven JS. Relationship between dental plaque indices and bacteria in dental plaque and those in saliva. J Dent Res 1987; 66(9): 1499-1502. 